\title{
REVIEW
}

\section{In Vivo Functions of GPR30/GPER-1, a Membrane Receptor for Estrogen: From Discovery to Functions In Vivo}

\author{
YoICHI MIZUKAMI \\ The Center for Gene Research, Yamaguchi University, Yamaguchi 755-8505, Japan
}

\begin{abstract}
Summary. G protein-coupled receptor 30/G protein-coupled estrogen receptor-1 (GPR30/GPER-1) was reported as a novel membrane receptor for estrogen in 2005. However, the research on GPR30 has produced conflicting reports with regard to its intracellular localization, the tissue distribution of its expression, and some its functions. Recently, in addition to the finding of G-1, a GPR30 agonist, GPR30 KO mice have been produced in laboratories, and this has significantly increased the confidence in the data. In this review, the intrinsic appearance of GPR30 is approached based mainly on data obtained in vivo.
\end{abstract}

Key words: GPR30, Membrane, GPCR, Estrogen, In vivo

MANY RECEPTORS of steroids hormones including estrogen (Estradiol, E2) associate with nuclear receptors, and function as transcription factors. Since the hydrophobic steroid structure of E2 makes it easy to pass through the cell membrane, it is thought to be unlikely to act on the cell membrane through association with cell surface receptors. However, it is known that various events, such as calcium influx and the production of nitric monoxide (NO) elicited by E2, could be observed within a few minutes after its stimulation. When this time course is taken into consideration, it appears that these events are induced without nuclear receptors, i.e., transcription factors. Therefore, the idea that a novel receptor for E2 exists on the cell surface has long been supported despite the high hydrophobicity of E2.

Research on this proposed cell surface E2 receptor was addressed aggressively, and a classical estrogen receptor (ER) $\alpha$, or its S-palmitoylated ER variant, was

Received Nov. 13, 2009; Accepted Nov. 16, 2009 as K09E-332 Released online in J-STAGE as advance publication Dec. 8, 2009

Correspondence to: Yoichi MIZUKAMI, Ph.D., Center for Gene Research, Yamaguchi University, 1-1-1 Minami-Kogushi, Ube, Yamaguchi 755-8505, Japan. E-mail: mizukami@yamaguchi-u.ac.jp This work was supported in part by grants-in-aid from the Ministry of Education, Science and Culture of Japan, the Takeda Science Foundation, and the Novartis Foundation (Japan) for the Promotion of Science. found to be localized in the cell membrane with caveolin, and to form complexes with trimeric $G$ protein [1-3]. Some ER-deficient breast cancer cells proliferate in response to E2, suggesting that a novel estrogen receptor other than ER may also exist on the cell surface. In 2002, the ER-X and SIX-sensitive receptors, E2-sensitive seven transmembrane receptors, were reported as membrane receptors for E2, although their molecular structures have yet to be clarified $[4,5]$. In neuronal cells, it was reported that a glutamate receptor is sensitive to E2 [6]. Furthermore, it has been reported that a novel cell surface receptor of E2 may exist in sex organs, but its amino acid sequence has not been determined.

We previously reported that GPR30 (also designated rat GPR41) is rapidly induced in the cardiomyocyte ischemia model, and that its induction is associated with apoptotic cell death during ischemia and reperfusion [7]. Another group has cloned GPR30 as a gene expressed

Abbreviations used: NO, nitric monoxide; E2, estradiol; ER, estrogen receptor; GPR30, G protein-coupled receptor 30; GPER-1, G protein-coupled estrogen receptor-1; EGF, epidermal growth factor; PDZ, PSD-95/Disc large/Zonula occludens-1; GPCR, G protein-coupled receptors; MMP, matrix metalloproteinase; HBEGF, heparin-binding EGF-like growth factor; CTGF, connective tissue growth factor; GLUT2, glucose transporter 2; EAE, Experimental autoimmune encephalomyelitis; OVX, Ovariectomy; Ang II, Angiotensin II; 5-HTP, 5-hydroxytryptophan. 
in blood vessels using a hypertensive model [8].

We thought that GPR30 might be a receptor for a cytokine or a receptor working in the cardiovascular system with a peptide ligand because GPR30 shows weak homology with a cytokine receptor [9]. However, several groups initially identified E2 as a ligand candidate for GPR30 because GPR30 was cloned based on the difference in gene expression in response to E2 in breast cancer cells [10]. Thomas et al. reported that E2 activates GPR30 in MCF-7 cells [11]. Finally, Revankar et al. showed that an orphan receptor, GPR30, is a receptor for E2 in the endoplasmic reticulum in 2005 [12]. After this discovery, it was shown by several groups, including ours, that GPR30 in the plasma membrane is activated by E2 $[13,14]$.

\section{A. Basic structure of GPR30}

Human GPR30 is located in chromosome 7p22.3, and is composed of three exons. Exon3 coincides with the amino acid coding region of GPR30. Based on linkage analysis, the region of the chromosome containing GPR30 is thought to be related to familial hypertensive disease in humans [15].

It has been reported that the AP-1 site that exists in the second intron is a transcriptional regulatory region of GPR30 activated in response to EGF [16]. There is a possibility that some of the transcript products for GPR30 are expressed in response to stimulation, because the AP- 1 site in intron 2 cannot transcribe Exons1 and 2 of GPR30. GPR30 is a G protein-coupled seven-transmembrane receptor, and human GPR30 comprises 375 amino acids with a theoretical molecular mass of approximately $41 \mathrm{kDa}$. It is thought that the $\mathrm{N}$-terminus is located outside of the cell, and that aspartic acid residues in the terminal region might be modified by glycosylation if GPR30 is localized in the plasma membrane. It is speculated that the ligand associates with the N-terminal domain to activate the receptor. Trimeric $\mathrm{G}$ protein is presumed to bind to the $3^{\text {rd }}$ loop of the intracellular domain based on the molecular structure. A PDZ domain appears to be in the C-terminal region of GPR30, but its physiological role is unknown.

\section{B. Intracellular localization of GPR30}

There are reports that GPR30 localizes in both the endoplasmic reticulum and Golgi apparatus [12, 17], and that GPR30 is present in the plasma membrane $[13,14]$, although a consensus about this has yet to be reached. In general, the data on the localization of GPCR in the endoplasmic reticulum and Golgi apparatus have to be evaluated carefully because the overexpression of exogenous genes often leads to an accumulation in the endoplasmic reticulum due to the use of a strong promoter and the effects of fusion proteins such as GFP. It is also necessary that the epitope sequences of the antibody present in the N-terminal region of GPCR should be noted. In the case of an antibody that recognizes a tag protein introduced into the N-terminal region of GPCR, it is possible that the antibody will be unable to recognize the epitope sequence following glycosylation of the N-terminal region in the Golgi apparatus. Unless GPCR on the plasma membrane is detected in some way, unmodified GPCR in the Golgi apparatus and endoplasmic reticulum will be stained, while that in the plasma membrane will remain unobserved. The anti-GPCR antibody has to be confirmed to recognize glycosylated GPCR through the use of immunoblotting. The localization of GPR30 in the plasma membrane has been reported by several groups, including ours, but it is not mysterious that GPR30 is observed in the endoplasmic reticulum and Golgi apparatus during the process of protein synthesis of the receptor. We could not find a commercially available antibody that accurately recognizes GPR30, and so we produced our own antibody for use in this study. Another group has suggested that many commercial antibodies for GPR30 react with proteins other than GPR30 by using $\mathrm{KO}$ mice, indicating that it is difficult to detect the GPR30 protein in tissues. There is a possibility that the use of insufficiently specific antibodies has led to the confusion concerning the localization of GPR30. At the least, the specificity of the antibody has to be confirmed by observing the disappearance of staining in the presence of an antigen peptide.

\section{Expression of GPR30 mRNA}

Up to now, data on the expression of the GPR30 mRNA in tissues has not necessarily produced a consensus result, although various methods were used including northern blotting, RT-PCR methods, and RNase protection assays [9, 10, 18-21] (Table 1). The mRNA for GPR30 appears to be expressed extensively in most tissues as judged from the overall reports. 
Table 1. Tissue distribution of GPR30 expression

\begin{tabular}{|c|c|c|c|c|c|c|c|}
\hline Tissues & $\begin{array}{l}\text { northern } \\
\text { blotting }\end{array}$ & $\begin{array}{l}\text { northern } \\
\text { blotting }\end{array}$ & $\begin{array}{l}\text { northern } \\
\text { blotting }\end{array}$ & RT-PCR & RT-PCR & $\begin{array}{l}\text { RNAse } \\
\text { protection } \\
\text { assay }\end{array}$ & LacZ-reporter mice \\
\hline Heart & $\triangle$ & () & (a) & $\triangle$ & 0 & $\bigcirc$ & \\
\hline Brain & $\times$ & 0 & (0) & () & $\bigcirc$ & $\bigcirc$ & $\begin{array}{l}\text { 1. smooth muscle cells } \\
\text { in brain } \\
\text { 2. neurons in cortex and } \\
\text { polymorphic layer of } \\
\text { dentate gyrus } \\
\text { 3. pituitary gland }\end{array}$ \\
\hline Lung & (2) & 0 & 0 & $\triangle$ & 0 & 0 & \\
\hline Liver & (2) & O & 0 & $\times$ & $\triangle$ & $x$ & \\
\hline Skeletal muscle & $\times$ & $\triangle$ & 0 & () & $(-)$ & $\triangle$ & \\
\hline Kidney & $\times$ & $\times$ & 0 & 0 & 0 & 0 & \\
\hline Placenta & $\times$ & () & () & $(-)$ & $(-)$ & $(-)$ & \\
\hline Pancreas & $\triangle$ & 0 & 0 & $(-)$ & $(-)$ & $(-)$ & (a) \\
\hline Spleen & 0 & $(-)$ & $(-)$ & $(-)$ & $\circ$ & $\times$ & \\
\hline Thymus & $\times$ & $(-)$ & $(-)$ & $(-)$ & $(-)$ & $x$ & \\
\hline Lymph node & $\triangle$ & $(-)$ & $(-)$ & $(-)$ & $(-)$ & $\triangle$ & \\
\hline Testis & $\times$ & $(-)$ & $(-)$ & $(-)$ & $(-)$ & $\times$ & (2) (blood vessel) \\
\hline Ovary & 0 & $(-)$ & $(-)$ & $(-)$ & $(-)$ & 0 & \\
\hline Bone marrow & $\bigcirc$ & $(-)$ & $(-)$ & $(-)$ & $(-)$ & () & \\
\hline Others & $\begin{array}{c}\text { Colon, } \\
\text { Prostate, Fetal } \\
\text { liver }(+)\end{array}$ & & & & & $\begin{array}{c}\text { Stomach, } \\
\text { Duodenum, } \\
\text { Adrenal gland } \\
(+)\end{array}$ & $\begin{array}{l}\text { 1. endothelial cells in } \\
\text { small artery vessels in } \\
\text { multiple tissues } \\
\text { 2. gastric chief cells in } \\
\text { stomach } \\
\text { 3. medulla of adrenal } \\
\text { gland } \\
\text { 4. blood vessels in } \\
\text { thyroid gland, harderian } \\
\text { gland and coagulating } \\
\text { gland }\end{array}$ \\
\hline ref. & 18) & 10) & 9) & 20) & 19) & 21) & 19) \\
\hline
\end{tabular}

Recently, Isensee et al. have succeeded in producing GPR30 KO mice with a LacZ gene introduced downstream of the GPR30 promoter, causing research in this field to be greatly advanced [19]. In these mice, GPR30 expression is limited to the blood vessels in the brain and the arteries in skeletal muscles and adipocytes. The expression of GPR30 shows a unique distribution. The expression pattern in blood vessels may produce the impression that there is ubiquitous expression in most tissues. In peripheral blood vessels, the GPR30 mRNA is expressed in the arterial endothelium, consistent with the physiological effect in which E2 induces the relaxation of blood vessels through NO produced in the endothelium. It is necessary to note the occurrence of high pressure and oxidative stress in the tissues during sampling, because the GPR30 mRNA is rapidly induced in response to stress. Other than blood vessels, the data obtained from LacZexpressing mice indicates the GPR30 mRNA to be highly inducible in digestive tissues including the stomach, pancreas, and duodenum. An interesting observation that the expression of GPR30 is mainly observed in the exocrine cells of the digestive tissues has been obtained in mice [19]. The expression of GPR30 in sexual organs has not been analyzed in detail up to now.

\section{Signal transduction of GPR30}

Since breast cancer cells proliferate in response to E2, E2 antagonists have been used for breast cancer therapy. However, relapse and metastasis have frequently been observed during therapy involving E2 antagonists, suggesting the possibility that a signal pathway other than in the ER in response to E2 may be present in breast cancer cells. It has been noted that GPR30 acts as a receptor in an alternative pathway of E2 activation. In studies of the signal pathways of GPR30, much of the data have been obtained 
using the breast cancer cell line MCF-7 and SkBr (Fig. 1). E2 associates with GPR30, a membrane receptor, leading to the activation of the trimeric $G$ protein in breast cancer cell lines. The $\alpha$ subunit in the activated trimeric $G$ protein induces the activation of adenylate cyclase, which results in the production of c-AMP. On the other hand, the $\beta$ and $\gamma$ subunits of the G protein activate Src tyrosine kinase, which binds to integrin $\alpha 5 \beta 1$ through an adaptor protein, Shc. This complex activates matrix metalloproteinase (MMP), and the activated MMP degrades pro-HB-EGF, which releases HB-EGF into the extracellular space. HB-EGF activates the EGF receptor via an autocrine/paracrine mechanism, leading to the activation of PI-3K. The activated EGF receptor also induces ERK activation $[22,23]$. In a recent paper, it was reported that the activation of ERK through GPR30 after E2 stimulation results in the secretion of a growth factor, CTGF, into the extracellular space, and that this secretion is involved in the proliferation of breast cancer cells [24]. These signal pathways in response to E2 appear to lead to the proliferation of breast cancer cells.

In other cell types, it has been reported that GPR30 is involved in apoptotic cell death and cell cycle arrest. Therefore, a pathway unrelated to the signal that leads to cell proliferation in cancer cells might be activated by GPR30 in other cell types. Further investigation is needed to clarify GPR30 signal transductions [25, 26].

\section{E. Biological functions of GPR30}

The discovery of G-1, an artificial agonist of GPR30 [27], and the production of GPR30 KO mice have led to progress in clarifying the biological functions of GPR30 (Table 2).

\section{Immunological system}

The phenotype of GPR30 KO mice was first shown in the immunological system. Wang et al. demonstrated that GPR30 was required for thymocyte apoptosis that occurs preferentially in $\mathrm{T}$ cell receptor $\beta$ chain ${ }^{\text {-low }}$ double-positive thymocytes using GPR30-deficient mice, and that G-1 induced thymotic atrophy and thymocyte apoptosis [25]. They also showed that the GPR30induced suppression of $\mathrm{CD}^{+}{ }^{+} \mathrm{Foxp}^{+}{ }^{+} \mathrm{T}$ regulatory cells has a protective effect on experimental autoimmune encephalomyelitis, an animal model of multiple sclerosis [28]. These findings have been confirmed by other groups, and it is expected that the mechanism

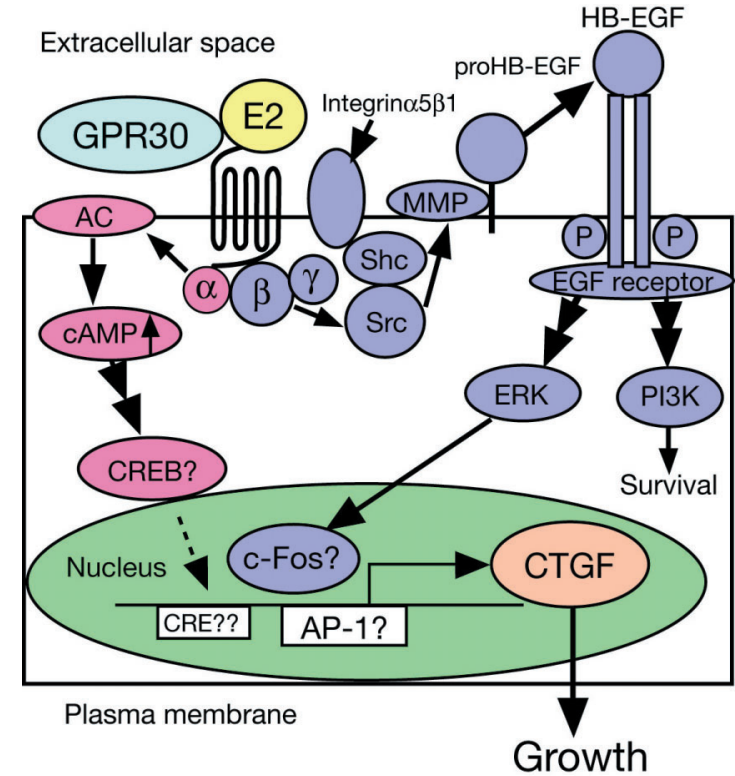

Fig. 1. Signal transduction of cell growth by E2 through GPR30 in breast cancer cells.

E2 associates with GPR30, a membrane receptor, leading to the activation of trimeric $G$ protein in breast cancer cells. The $\alpha$ subunit of the activated trimeric G protein induces the activation of adenylate cyclase while the $\beta$ and $\gamma$ subunits activate Src tyrosine kinase. The complex activates MMP, and the activated MMP releases HB-EGF into the extracellular space. The activated EGF receptor also induces ERK activation. The activation of ERK through GPR30 following E2 stimulation leads to the secretion of a growth factor, CTGF, into the extracellular space. (ref. 22 and 23).

of the induction of T cell apoptosis by GPR30 will be clarified in the near future.

\section{Circulatory system}

It has been reported that G-1 reduces systolic blood pressure in ovariectomized female mRen2 Lewis rats, an estrogen-sensitive model of hypertension, suggesting that the renin-angiotensin system is involved in the reduction of blood pressure through GPR30 [29]. In normal rats, the infusion of G-1 results in an acute reduction in mean arterial blood pressure within 2 min [30]. The effect of G-1 has been confirmed using $\mathrm{GPR}^{-/-}$mice. The deletion of GPR30 from mice attenuates the G-1-induced relax of the carotid arteries, and there is no observed sex difference in the reductive effect of GPR30 [30]. The expression of the GPR30 mRNA is observed in the endothelium of the peripheral vessels of LacZ-introduced mice [19]. The production of NO by E2 in endothelial cells may be mediated 
Table 2. GPR30-related deseases

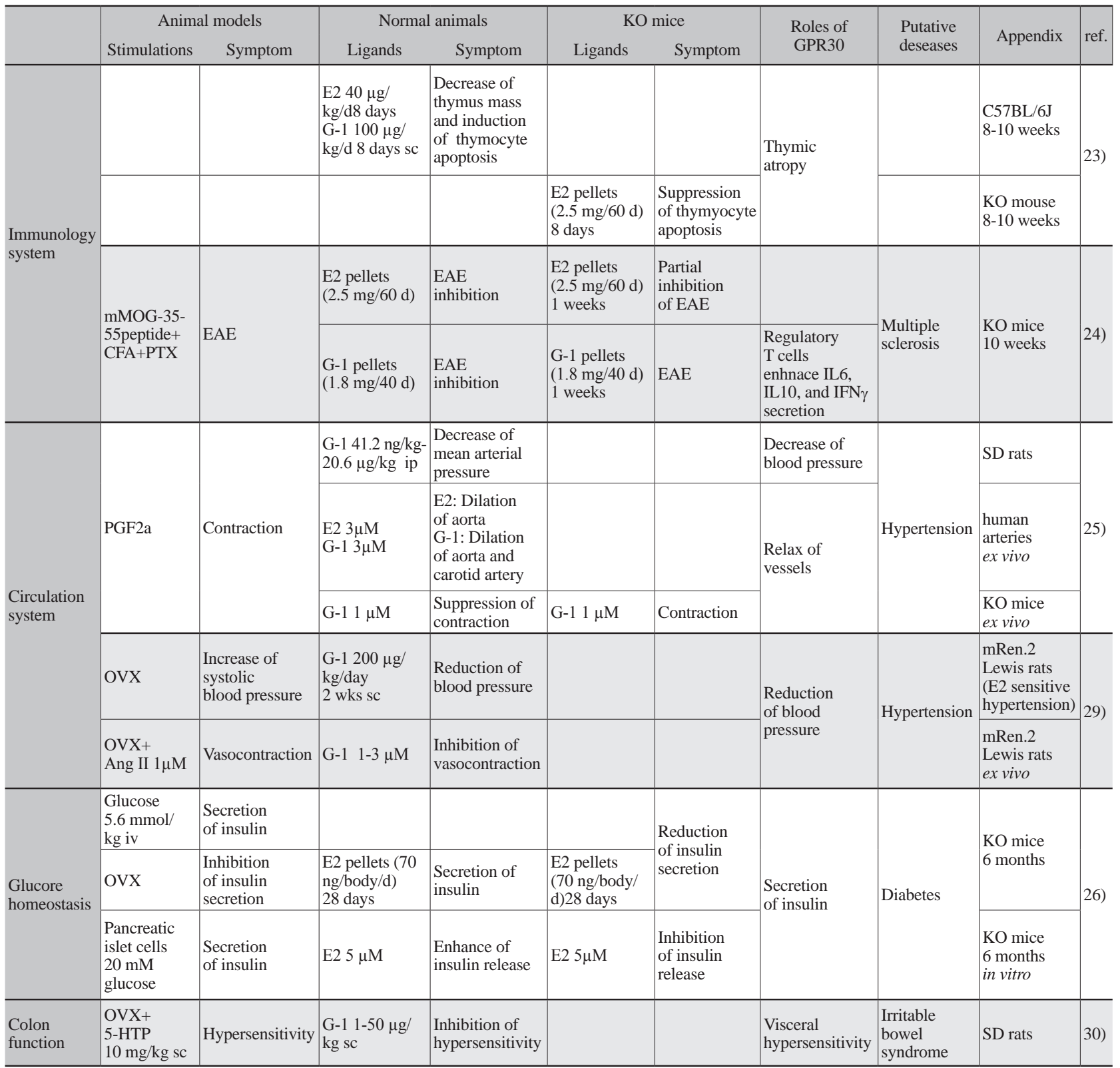

by GPR30, thus leading to the reduction in blood pressure. Clarification of the NO production pathway by $\mathrm{E} 2$ is an issue that needs to be addressed further.

\section{Glucose homeostasis}

GPR30 is expressed in pancreatic islet cells in mice, and adult female GPR30 $0^{-/}$mice do not exhibit the E2-induced release of insulin [20]. This result is consistent with experiments using isolated pancreatic islet cells in vitro [20]. There are no differences in the expressions of glucose-related genes such as GLUT2 and glucokinase in GPR30 ${ }^{-1}$ mice as compared with wild type mice. Thus GPR30 may act in regulating the process of insulin release after E2 stimulation. GPR30 mRNA is also expressed in secretory gland cells and mammary gland epithelial cells, and GPR30 may be involved in the secretion pathway of breast fluid and hormones including insulin. It has been reported that the regulation of blood glucose levels is unaffected in GPR30 $0^{-/}$mice. In reports in which differences in glucose levels were observed, mice older than 3 months age were used, and it would be interest- 
ing if only aged mice show the regulation of glucose levels through GPR30 activation.

\section{Concluding remarks}

The data obtained using GPR30 ${ }^{-/}$mice and the G-1 agonist indicate that the roles of GPR30 in the cardiovascular and immunological systems are mostly consistent with previous findings observed by E2 treatment, probably through its activity as a membrane receptor. It is expected that GPR30 plays important roles in early E2-induced events that take place on the membrane. On the other hand, the concentration of E2 needed for GPR30 activation is higher than that required ER activation. In our laboratory, we have found that high concentrations of E2 and G-1 are needed to activate GPR30 as shown in Figure 2. Further investigations are needed to clarify whether these E2 concentrations are physiological in living animals, or whether another physiological ligand is present in cells.

There are also reports that GPR30 is a classical ER cofactor; however, experimental evidence for this is inadequate [31]. If GPR30 acts as a cofactor in the

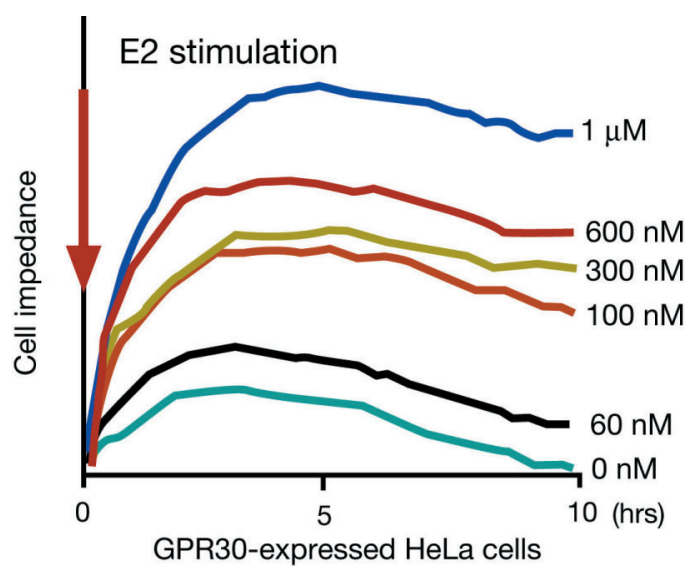

Fig. 2. Cell impedance in GPR30-expressing HeLa cells in response to E2.

FLAG-GPR30 was introduced into HeLa cells, and cell impedance was determined in the presence of the indicated concentrations of E2 using xCELLigence (Roche).

ER, the E2 concentration for GPR30 activation might be equal to that for ER activation. Direct evidence such as crystal structure analysis is necessary to clarify this point.

\section{References}

1. Li L, Haynes MP, Bender JR (2003) Plasma membrane localization and function of the estrogen receptor alpha variant (ER46) in human endothelial cells. Proc Natl Acad Sci U S A 100: 4807-4812.

2. Wyckoff MH, Chambliss KL, Mineo C, Yuhanna IS, Mendelsohn ME, Mumby SM, Shaul PW (2001) Plasma membrane estrogen receptors are coupled to endothelial nitric-oxide synthase through Galpha(i). $J$ Biol Chem 276: 27071-27076.

3. Boulware MI, Kordasiewicz H, Mermelstein PG (2007) Caveolin proteins are essential for distinct effects of membrane estrogen receptors in neurons. J Neurosci 27: 9941-9950.

4. Toran-Allerand CD, Guan X, MacLusky NJ, Horvath TL, Diano S, Singh M, Connolly ES, Jr., Nethrapalli IS, Tinnikov AA (2002) ER-X: a novel, plasma membrane-associated, putative estrogen receptor that is regulated during development and after ischemic brain injury. J Neurosci 22: 8391-8401.

5. Qiu J, Bosch MA, Tobias SC, Krust A, Graham SM, Murphy SJ, Korach KS, Chambon P, Scanlan TS, Ronnekleiv OK, Kelly MJ (2006) A G-protein-coupled estrogen receptor is involved in hypothalamic control of energy homeostasis. J Neurosci 26: 5649-5655.

6. Boulware MI, Weick JP, Becklund BR, Kuo SP, Groth RD, Mermelstein PG (2005) Estradiol activates group I and II metabotropic glutamate receptor signaling, leading to opposing influences on cAMP response elementbinding protein. J Neurosci 25: 5066-5078.

7. Kimura M, Mizukami Y, Miura T, Fujimoto K, Kobayashi S, Matsuzaki M (2001) Orphan G proteincoupled receptor, GPR41, induces apoptosis via a p53/ Bax pathway during ischemic hypoxia and reoxygenation. J Biol Chem 276: 26453-26460.

8. Takada Y, Kato C, Kondo S, Korenaga R, Ando J (1997) Cloning of cDNAs encoding $\mathrm{G}$ protein-coupled receptor expressed in human endothelial cells exposed to fluid shear stress. Biochem Biophys Res Commun 240: 737-741.

9. Feng Y, Gregor P (1997) Cloning of a novel member of the $\mathrm{G}$ protein-coupled receptor family related to peptide receptors. Biochem Biophys Res Commun 231: 651-654.

10. Carmeci C, Thompson DA, Ring HZ, Francke U, Weigel RJ (1997) Identification of a gene (GPR30) with homology to the G-protein-coupled receptor su- 
perfamily associated with estrogen receptor expression in breast cancer. Genomics 45: 607-617.

11. Thomas P, Pang Y, Filardo EJ, Dong J (2005) Identity of an estrogen membrane receptor coupled to a $\mathrm{G}$ protein in human breast cancer cells. Endocrinology 146: 624-632.

12. Revankar CM, Cimino DF, Sklar LA, Arterburn JB, Prossnitz ER (2005) A transmembrane intracellular estrogen receptor mediates rapid cell signaling. Science 307: 1625-1630.

13. Funakoshi T, Yanai A, Shinoda K, Kawano MM, Mizukami Y (2006) G protein-coupled receptor 30 is an estrogen receptor in the plasma membrane. Biochem Biophys Res Commun 346: 904-910.

14. Filardo E, Quinn J, Pang Y, Graeber C, Shaw S, Dong J, Thomas P (2007) Activation of the novel estrogen receptor G protein-coupled receptor 30 (GPR30) at the plasma membrane. Endocrinology 148: 3236-3245.

15. Lafferty AR, Torpy DJ, Stowasser M, Taymans SE, Lin JP, Huggard P, Gordon RD, Stratakis CA (2000) A novel genetic locus for low renin hypertension: familial hyperaldosteronism type II maps to chromosome 7 (7p22). J Med Genet 37: 831-835.

16. Albanito L, Sisci D, Aquila S, Brunelli E, Vivacqua A, Madeo A, Lappano R, Pandey DP, Picard D, Mauro L, Ando S, Maggiolini M (2008) Epidermal growth factor induces $G$ protein-coupled receptor 30 expression in estrogen receptor-negative breast cancer cells. Endocrinology 149: 3799-3808.

17. Sakamoto H, Matsuda K, Hosokawa K, Nishi M, Morris JF, Prossnitz ER, Kawata M (2007) Expression of $\mathrm{G}$ protein-coupled receptor-30, a G protein-coupled membrane estrogen receptor, in oxytocin neurons of the rat paraventricular and supraoptic nuclei. Endocrinology 148: 5842-5850.

18. Owman C, Blay P, Nilsson C, Lolait SJ (1996) Cloning of human cDNA encoding a novel heptahelix receptor expressed in Burkitt's lymphoma and widely distributed in brain and peripheral tissues. Biochem Biophys Res Commun 228: 285-292.

19. Isensee J, Meoli L, Zazzu V, Nabzdyk C, Witt H, Soewarto D, Effertz K, Fuchs H, Gailus-Durner V, Busch D, Adler T, de Angelis MH, Irgang M, Otto C, Noppinger PR (2009) Expression pattern of G protein-coupled receptor 30 in LacZ reporter mice. Endocrinology 150: 1722-1730.

20. Martensson UE, Salehi SA, Windahl S, Gomez MF, Sward K, Daszkiewicz-Nilsson J, Wendt A, Andersson N, Hellstrand P, Grande PO, Owman C, Rosen CJ, Adamo ML, Lundquist I, Rorsman P, Nilsson BO, Ohlsson C, Olde B, Leeb-Lundberg LM (2009) Deletion of the $G$ protein-coupled receptor 30 impairs glucose tolerance, reduces bone growth, increases blood pressure, and eliminates estradiol-stimulated insulin re- lease in female mice. Endocrinology 150: 687-698.

21. Otto C, Fuchs I, Kauselmann G, Kern H, Zevnik B, Andreasen P, Schwarz G, Altmann H, Klewer M, Schoor M, Vonk R, Fritzemeier KH (2009) GPR30 does not mediate estrogenic responses in reproductive organs in mice. Biol Reprod 80: 34-41.

22. Filardo EJ, Thomas P (2005) GPR30: a seven-transmembrane-spanning estrogen receptor that triggers EGF release. Trends Endocrinol Metab 16: 362-367.

23. Quinn JA, Graeber CT, Frackelton AR, Jr., Kim M, Schwarzbauer JE, Filardo EJ (2009) Coordinate regulation of estrogen-mediated fibronectin matrix assembly and epidermal growth factor receptor transactivation by the G protein-coupled receptor, GPR30. Mol Endocrinol 23: 1052-1064.

24. Pandey DP, Lappano R, Albanito L, Madeo A, Maggiolini M, Picard D (2009) Estrogenic GPR30 signalling induces proliferation and migration of breast cancer cells through CTGF. EMBO J 28: 523-532.

25. Wang C, Dehghani B, Magrisso IJ, Rick EA, Bonhomme E, Cody DB, Elenich LA, Subramanian S, Murphy SJ, Kelly MJ, Rosenbaum JS, Vandenbark AA, Offner H (2008) GPR30 contributes to estrogeninduced thymic atrophy. Mol Endocrinol 22: 636-648.

26. Teng J, Wang ZY, Prossnitz ER, Bjorling DE (2008) The $\mathrm{G}$ protein-coupled receptor GPR30 inhibits human urothelial cell proliferation. Endocrinology 149: 40244034.

27. Bologa CG, Revankar CM, Young SM, Edwards BS, Arterburn JB, Kiselyov AS, Parker MA, Tkachenko SE, Savchuck NP, Sklar LA, Oprea TI, Prossnitz ER (2006) Virtual and biomolecular screening converge on a selective agonist for GPR30. Nat Chem Biol 2: 207212.

28. Wang C, Dehghani B, Li Y, Kaler LJ, Proctor T, Vandenbark AA, Offner H (2009) Membrane estrogen receptor regulates experimental autoimmune encephalomyelitis through up-regulation of programmed death 1. J Immunol 182: 3294-3303.

29. Lindsey SH, Cohen JA, Brosnihan KB, Gallagher PE, Chappell MC (2009) Chronic treatment with the G protein-coupled receptor 30 agonist G-1 decreases blood pressure in ovariectomized mRen2.Lewis rats. Endocrinology 150: 3753-3758.

30. Haas E, Bhattacharya I, Brailoiu E, Damjanovic M, Brailoiu GC, Gao X, Mueller-Guerre L, Marjon NA, Gut A, Minotti R, Meyer MR, Amann K, Ammann E, Perez-Dominguez A, Genoni M, Clegg DJ, Dun NJ, Resta TC, Prossnitz ER, Barton M (2009) Regulatory role of $\mathrm{G}$ protein-coupled estrogen receptor for vascular function and obesity. Circ Res 104: 288-291.

31. Levin ER (2009) G protein-coupled receptor 30: estrogen receptor or collaborator? Endocrinology 150: 1563-1565. 